\title{
Practices of Care from Educators at Institutional Shelters for Children
}

\author{
Lilian de Jesus Fontel Cunha Donato, Celina Maria Colino Magalhaes, Laiane da Silva Corrêa \\ Universidade Federal do Pará, Belém, Brazil \\ Email: laicorrea@gmail.com
}

How to cite this paper: de Jesus Fontel Cunha Donato, L., Magalhaes, C. M. C., \& da Silva Corrêa, L. (2017). Practices of Care from Educators at Institutional Shelters for Children. Psychology, 8, 1161-1170. https://doi.org/10.4236/psych.2017.88075

Received: April 26, 2017

Accepted: June 13, 2017

Published: June 16, 2017

Copyright $\odot 2017$ by authors and Scientific Research Publishing Inc. This work is licensed under the Creative Commons Attribution International License (CC BY 4.0).

http://creativecommons.org/licenses/by/4.0/

\section{(c) (i) Open Access}

\begin{abstract}
Shelter is a last resort in cases of suspected or threatened violation of rights in the Statute of the Child and Adolescent. The literature suggests that quality of care offered to children is one of the factors necessary to ensure the protective nature of the institutional care. This study aimed to investigate the profile and care practices of educators in the state of Pará, comparing two contexts, the metropolitan region of Belém (RMB) and the interior region of the state (IE). Data were collected by semi-structured interviews with 110 educators from 11 shelters in the state of Pará. The results show that the RMB educators have higher average service time than IE group, and significant differences were detected in 14 care practices between the groups. Our findings corroborate the literature on the importance of training and valuing the educator in order to provide a higher quality service.
\end{abstract}

\section{Keywords}

Care Practices, Profile, Educators, Institutional Care, Child Care

\section{Introduction}

The practice of housing young people and children in care institutions dates back to Colonial Brazil and brings in its scope caregiving traditions and educational practices to the poor and the deprived of society (Rizzini \& Rizzini, 2004). With the Statute of the Child and Adolescent-ECA, Law 8069 (Brazil, 1990), shelter programs were defined as a temporary and exceptional protection measure in situations where the child or adolescent is at personal and social risk, and established as principles adopted, the preservation of family ties and participation in the life of the local community.

In 2006, the National Council for the Rights of Children and Adolescents (CONANDA), together with the National Council of Social Assistance (CNAS), prepared the National Plan for the Promotion, Protection and Defense of the 
Right of Children and Adolescents to Family and Community Living (Brazil, 2006), which brought discussions about ensuring the rights of children and adolescents under state custody. In this document, the term Institutional Shelter was used for the so-called shelter programs, later consolidated by the National Adoption Law (Law 12010/2009). From this document, it was established the different institutional arrangements offered to children and adolescents, namely: Institutional shelter for small groups, Household and Halfway House. These should provide assistance to the child and adolescent regarding the reception, care and space for socialization and development, as well as the possibility of a positive and stable relationship with the caregiver, guaranteeing spaces for keeping personal objects and recording the life history and development of each child and adolescent (Brazil, 2006).

Subsequently, the Ministry of Development and Fight against Hunger published the guide "Technical Guidelines: Shelter Service for Children and Adolescents" (Orientações Técnicas: Serviço de Acolhimento Para Crianças e Adolescentes-Brazil, 2009), which sets guidelines for the modalities of shelter services. In this document, the Institutional Shelter is defined as a home-like service for a maximum of 20 children and adolescents, located in residential areas and inserted in the community, offering a warm environment and conditions for care with dignity, respect to individuality, favoring family and community living. It is important to highlight the figure of the educator/caregiver, person responsible for basic care such as food, hygiene, protection and educating the users of the host institutions, with minimum schooling level (high school) and preferably with experience in attending children and adolescents (Brazil, 2009). The role of professionals who assist children and adolescents is to educate and care, so that the educator works as the figure that will meet the immediate needs of children, as well as serve as models for a healthy socialization.

The national and international literature discuss the impacts of distancing from the family and child development in host institutions, especially in the context of cognitive, social and emotional development in early childhood (Calheiros, Garrido, Lopes, \& Patrício, 2015; Cavalcante, 2008; Golin \& Benetti, 2013; Lima \& Lima, 2012; Müller, 2014), considering that this stage of life is marked by the need for care that ensure survival and promote the biopsychosocial development of children. In a more recent discussion, the literature (Coutinho \& Sani, 2010; Quiroga \& Hamilton-Giachritsis, 2016) sustains that the institutional shelter process may or may not present a risk to children's development, so it should be considered their life history, the institutional environment and the quality of care provided.

Corrêa and Cavalcante (2012) point out that the manifestation of pro-social behaviors by young children in host institutions may be related to direct caregivers, since they can play the role of strengthening the internal motivations of helping others when their actions serve as examples of generosity and empathy, there is the development of a secure attachment pattern, and the care provided is attentive and responsive to the demands of the child. In this sense, an educator 
who provides relational models of healthy social and emotional functioning can provide a development environment with protection and support for the child to deal with the shelter process (Calheiros et al., 2015; Coutinho \& Sani, 2010; Golin \& Benetti, 2013; Lima \& Lima, 2012).

However, the care work in institutional shelter is marked by the demands of technical training courses, emotional and material support by the educators (Corrêa \& Cavalcante, 2012; Nogueira \& Costa, 2005; Pereira, Pereira, \& Johnson, 2010; Tinoco \& Franco, 2011). The availability of these resources to professionals is pointed out in the literature as an important factor for the provision of a quality service (Moré \& Sperancetta, 2010; Nelson, Fox, \& Zeanah, 2014; Quiroga \& Hamilton-Giachritsis, 2016).

In this sense, the professionals who provide care for children represent aline of research in institutional shelter that can be considered recent and provides an understanding of the quality of care and relationships established between the educator and the children. Literature reviews emphasize the importance of studies on the profile, activities, roles and relationships that characterize the institutional shelter, considering also the cultural characteristics of the institutions in order to subsidize permanent training programs with professionals, and ensure the children's and adolescents' well-being (Corrêa,Cavalcante, Magalhães \& Reis, 2016; Moré \& Sperancetta, 2010; Quiroga \& Hamilton-Giachritsis, 2016).

These studies show that the presence of educators who are sensitive to children's needs can provide positive emotions (for example, well-being and safety), as well as providing models and stimulating the formation of new affective bonds and the development of autonomy in caring for their bodies and conflict resolution, allowing the maintenance of the physical, psychological and social development of children away from family life (Calheiros et al., 2015; Cavalcante, 2008; Lima \& Lima, 2012). However, the same works present the host institution and their elements from the perspective of few host institutions or in units located near the capital cities or metropolitan regions. Quiroga and Hamilton-Giachritsis (2016) question whether the same dynamics is representative of institutions located in a context different from metropolitan regions. Nevertheless, considering that a community located in the metropolitan region and another one away from urban centers correspond to the same reality can neglect differences underlying the adaptive practices and the availability of environmental resources.

It is thus considered that the quality of care practices offered to young children can directly influence their development, and therefore when they are removed from their family environment for reasons of violation or threat to their rights (for example, food, health, safety and leisure), they are sent to host institutions under the care of professionals. These places will be responsible for meeting the basic care needs and immediate emotional, social gaps left by families. Thus, the present study aimed to explore the profile and practices of care from educators in institutional shelters considering two contexts: the Metropolitan Region of Belém and Interior of the state of Pará. 


\section{Method}

\subsection{Participants}

The sample consisted of 110 educators from institutional shelters that were responsible for the daily care of children. These professionals were of both sexes, aged between 19 and 63 years, of which $91.8 \%$ were from the state of Pará. This was a non-probabilistic convenience sample whose selection criteria were exercising the function of educator for at least one month, being caregiver of child from zero to six years and accepting to participate in the research. Educators who worked in an institutional shelter exclusive for children with special needs were not included.

\subsection{Environment}

The institutions provided services for children from zero to six years old and worked at the mode of Institutional Shelter. They were located in four regions of the state of Pará (Metropolitan region of Belém, Caetés, Guamá and Tocantins), totaling 11 institutions.

\subsection{Instruments}

Data were collected through a semi-structured questionnaire (Cavalcante, 2008), composed of open and closed sub-items, grouped into four thematic axes, namely: (a) personal data, (b) professional data, (c) data on satisfaction with the profession and (d) data on care conceptions and practices. Regarding the survey of care practices, the instrument has a five-point likert scale, in which the educator judged the frequency with which he/she practiced, through the options " 1 $=$ never", " $2=$ rarely" " $3=$ sometimes", " $4=$ often" and " $5=$ always". The scale had 55 practices aimed at the care of children and adolescents, grouped in 16 assertions about the routine in an institutional environment, to mention: the arrival and preparation for the dismissal, the use of the moment of the meal for learning, how is the moment of preparation for sleep, promotion of independence in personal hygiene situations, educator/child social interaction, encouraging the development of children with limited mobility, conflict mediation, positive social interactions, encouragement and maintenance of family ties and/or bonds with foster family and talk about sexuality.

\subsection{Procedures}

The present study is a cross-sectional survey and is part of a larger study that investigated the profile, routine and care practices of shelter institutions in four regions of the state of Pará. Initially, all ethical procedures were performed, such as judicial authorization, approval by the social assistance secretariat of the municipalities and the management of the institution, and a favorable opinion was obtained from the ethics committee on research with human being, Health Sciences Institute, Federal University of Pará, record number 568265.

Data collection took place through a semi-structured interview preceded by the presentation of the project to the educator and consent in a Free and In- 
formed Consent. The interview occurred in the shelter institution, from October 2013 to March 2014, during the educator's work shift, and could be interrupted at any time at the request of the participant, guaranteeing the continuity of the service to the children.

After collection, the data were revised, categorized and converted into analysis variables in a spreadsheet for statistical analysis. With the completed database, it was decided to investigate educators and care practices aimed at children up to six years of age, since the early years are key to a person's biopsychosocial development.

For the analysis, the sample was divided into two groups, Metropolitan region of Belém (RMB), composed of educators from five shelters in the municipalities of Belém and Ananindeua and Interior of the State (IE) with educators from six units of the municipalities Castanhal, São Miguel do Guamá, Abaetetuba, Barcarena, Capanema and Tocantins. In this way, the sociodemographic profile of the educators in the RMB and IE were drawn, based on the information of the axes personal data and professional data. Care practices were investigated from the scale described above, from which 47 items directed to the care of children were selected. In order to check for possible differences between sociodemographic characteristics and care practices in the RMB and IE groups, it was used descriptive and inferential statistics, using Student's t-test and the non-parametric Mann-Whitney $U$ test, and adopted $\alpha \leq 0.05$ as a significance value.

\section{Results}

Regarding the profile of the RMB educators $(\mathrm{n}=77)$, all participants were women, $68.8 \%$ had children, the mean age was 39.58 years $(\mathrm{SD}=9.5)$, and $48.1 \%$ had higher education. With respect to the professional data, the mean service time found was 6.19 years $(\mathrm{SD}=5.99), 63.6 \%$ were part of the board of employees admitted by public selection, $63.2 \%$ had professional experience working with children and $31.2 \%$ attended some training course in the two years.

In the IE group ( $\mathrm{n}=33$ ), the majority were women, $84.8 \%$ had children, the mean age was 35.7 years $(\mathrm{SD}=8.4)$ and $24.2 \%$ had higher education. The professional data indicated that the mean service time was 2.5 years $(S D=2.32)$, $21.2 \%$ were employees admitted by public selection, $78.8 \%$ had experience working with child care and $63.6 \%$ had attended training courses in the last two years (See Table 1).

There were significant differences for the age group $(t=2.365, p=0.020)$, time of service at the shelter institution $(t=2.845, p=0.005)$ and participation in training courses $(t=-3.00, p=0.001)$ between RMB and IE groups, based on the Student's t-test for independent samples, considering a significance level of $\mathrm{p}$ $\leq 0.05$.

Table 2 lists the values of Mean rank, Mann-Whitney U-test and significance values of the care practices that presented significant differences between the $\mathrm{RMB}$ and IE groups. It is noteworthy that out of the 47 practices directed to the care of children, 14 presented significant differences between the groups. 
Table 1. Socio-demographic variables of educators from RMB and IE $(\mathrm{N}=110)$.

\begin{tabular}{|c|c|c|c|c|c|c|}
\hline \multirow{2}{*}{ Variables } & \multicolumn{2}{|c|}{$\begin{array}{c}\text { Metropolitan } \\
\text { Region }(n=77)\end{array}$} & \multicolumn{2}{|c|}{$\begin{array}{l}\text { Interior of the } \\
\text { State }(n=33)\end{array}$} & \multirow[t]{2}{*}{$\mathrm{t}$} & \multirow{2}{*}{$\mathrm{p}$} \\
\hline & $\mathbf{N}$ & $\%$ & $\mathbf{N}$ & $\%$ & & \\
\hline \multicolumn{7}{|l|}{ Sex } \\
\hline Female & 77 & 100 & 30 & 90.9 & \multirow{2}{*}{-2.75} & \multirow{2}{*}{0.007} \\
\hline Male & 0 & 0 & 3 & 9.9 & & \\
\hline \multicolumn{7}{|l|}{ Age group } \\
\hline$\leq 35$ & 26 & 33.8 & 19 & 57.6 & \multirow{2}{*}{2.365} & \multirow{2}{*}{0.02} \\
\hline$\geq 35$ & 51 & 66.2 & 14 & 42.4 & & \\
\hline \multicolumn{7}{|l|}{ Schooling level } \\
\hline Basic Education & 4 & 5.2 & 2 & 6.1 & \multirow{3}{*}{2.061} & \multirow{3}{*}{0.42} \\
\hline High School & 36 & 46.8 & 23 & 69.7 & & \\
\hline High Education & 37 & 48.1 & 8 & 24.2 & & \\
\hline \multicolumn{7}{|l|}{ Have children } \\
\hline Yes & 53 & 68.8 & 28 & 84.8 & \multirow{2}{*}{-1.75} & \multirow{2}{*}{0.82} \\
\hline No & 24 & 31.2 & 5 & 15.2 & & \\
\hline \multicolumn{7}{|l|}{ Time of Service } \\
\hline$\leq 12$ & 25 & 32.5 & 16 & 48.5 & \multirow{2}{*}{2.845} & \multirow{2}{*}{0.005} \\
\hline$\geq 12$ & 52 & 67.5 & 17 & 51.5 & & \\
\hline \multicolumn{7}{|l|}{ Work regime } \\
\hline Public selection & 49 & 63.6 & 7 & 21.2 & \multirow{2}{*}{-4.38} & \multirow{2}{*}{0.000} \\
\hline Temporary & 28 & 36.4 & 26 & 78.8 & & \\
\hline \multicolumn{7}{|l|}{ Capacitation course } \\
\hline Yes & 24 & 31.2 & 21 & 63.6 & \multirow{2}{*}{-3.30} & \multirow{2}{*}{0.001} \\
\hline No & 53 & 68.8 & 12 & 36.4 & & \\
\hline \multicolumn{7}{|c|}{ Experience with children } \\
\hline Yes & 51 & 66.2 & 26 & 78.8 & \multirow{2}{*}{1.315} & \multirow{2}{*}{0.191} \\
\hline No & 26 & 33.8 & 7 & 21.2 & & \\
\hline
\end{tabular}

Note: Student's t-test $\left({ }^{*} \mathrm{p} \leq 0.05 ;{ }^{* *} \mathrm{p} \leq 0.0005\right)$.

From the frequency data, it is suggested that IE educators tend to perform care practices more frequently than those in the RMB group, except for the practice "intervening in situations of physical, verbal and gestural aggression" in conflict situations.

\section{Discussion}

Considering the profile of the educators, in the two groups, IE educators are younger, have lower service time, and are in a temporary work situation, with a higher prevalence of education linked to high school and the presence of men working in the care function of children under seven years. Some of these variables are suggested by the Technical Guidelines (Brazil, 2009) as basic requirements, related to the role of educator. In contrast, the most recent literature in the area indicates the predominance of complete high school and/or high education and experience with the care for small children both in maternity and in the 
Table 2. Care practices that presented significant differences between the RMB and IE groups $(\mathrm{N}=110)$.

\begin{tabular}{|c|c|c|c|c|}
\hline \multirow{2}{*}{ Care practices } & \multicolumn{2}{|c|}{ Mean Rank } & \multirow{2}{*}{$\mathrm{U}$} & \multirow{2}{*}{$\mathrm{p}$} \\
\hline & RMB & IE & & \\
\hline $\begin{array}{l}\text { Receive the children and/or adolescents upon arrival } \\
\text { at the institution in a warm and affectionate manner }\end{array}$ & 52.0 & 63.7 & 999.5 & $.054^{*}$ \\
\hline $\begin{array}{l}\text { Prepare (accompany, encourage, organize) children } \\
\text { and/or adolescents to leave the shelter in a warm and } \\
\text { affectionate way }\end{array}$ & 51.1 & 65.9 & 928.0 & $.017^{*}$ \\
\hline \multicolumn{5}{|l|}{$\begin{array}{l}\text { Sit with the children and use the meal time for } \\
\text { learning }\end{array}$} \\
\hline Try and/or meet new foods & 51.1 & 65.8 & 932.0 & $.019^{*}$ \\
\hline Question about food preferences & 50.6 & 66.8 & 896.0 & $.012^{*}$ \\
\hline \multicolumn{5}{|l|}{ Help children relax and sleep } \\
\hline $\begin{array}{l}\text { Encourage the child and/or adolescent to make their } \\
\text { bed }\end{array}$ & 51.2 & 65.4 & 943.0 & $.012^{*}$ \\
\hline \multicolumn{5}{|l|}{$\begin{array}{l}\text { Use the time for hygiene to promote independence } \\
\text { among young children }\end{array}$} \\
\hline Button the clothes & 51.9 & 63.8 & 996.5 & $.050^{*}$ \\
\hline Diaper change & 51.2 & 65.5 & 940.5 & $.023^{*}$ \\
\hline \multicolumn{5}{|l|}{ Usually know how to appease conflict interactions } \\
\hline Intervenes in physical, verbal and gestural aggressions & 60.2 & 44.6 & 911.5 & $.002^{*}$ \\
\hline \multicolumn{5}{|l|}{ Talk and teach children about sexuality } \\
\hline Sexual relationship & 47.6 & 73.8 & 665.5 & $.000^{* *}$ \\
\hline Affective relationship & 50.5 & 67.2 & 885.5 & $.009^{*}$ \\
\hline Body transformation & 48.2 & 72.5 & 710.0 & $.000^{* *}$ \\
\hline Masturbation & 49.3 & 70.0 & 793.5 & $.000^{* *}$ \\
\hline Sexual violence & 47.1 & 75.0 & 626.0 & $.000^{\star *}$ \\
\hline DST & 43.8 & 82.7 & 373.0 & $.000^{* *}$ \\
\hline
\end{tabular}

Note: Mann-Whitney U-test $\left({ }^{*} \mathrm{p} \leq 0.05 ;{ }^{* *} \mathrm{p} \leq 0.0005\right)$.

time of service (Cavalcante, 2008; Corrêa et al., 2016; Magalhães, Costa, \& Cavalcante, 2011; Pereira et al., 2010; Tinoco \& Franco, 2011). It should be noted that the presence of the male figure in care may result in differentiated models for the development of the child, according to Bueno, Gomes and Crepaldi (2015). Thus, the presence of male caregivers could become a policy to be encouraged in the institutions, considering the roles they play in the development of children.

Data from the comparison of care practices indicate that there was no significant difference in more than $50 \%$ of the practices investigated which points to homogeneity of care practices in shelter institutions in the state of Pará. However, there were 14 practices with significant differences between RMB and IE groups. When analyzing the Mean Rank scores of the Mann-Whitney U-test and descriptive inferential statistics, it is noted that IE educators most often perform care practices aimed at: "reception at the institution", "preparation for the dismissal", "uses the moment of the meal to know the preferences of the children and encourages them to try new foods", "encourages children to make their own 
beds", "uses the time to button and close clothes, and diaper change to promote children's independence", and "talk and teach about sexuality". In relation to this last practice, the result is in agreement with the literature, which points out the difficulty of the educator in talking with the child about themes that can mobilize pain and suffering (Pereira et al., 2010; Tinoco \& Franco, 2011), once a portion of the children were referred to the institution for reasons of sexual violence.

The practice "intervened in situations of conflict, physical and verbal aggression" was used with higher frequency by the caregivers of the RMB group. Perhaps, the combination of variables, higher education and longer time of service tends to offer better intervention conditions in aggressive episodes and practice of quality care.

The fact that IE participants had more specific training courses in the area, may have contributed to a greater frequency of practices directed to daily care, aimed at the independence and autonomy of children. Nevertheless, the low stability in the function, considering that the contracts are provisional, puts at risk the execution of these practices in a stable way. In addition to the human and financial resources used to train educators.

The literature emphasizes that the process of housing in shelters can be a risk and protection factor for children away from family life, and the importance of investigations regarding the characteristics of educators and care practices to subsidize intervention and training plans (Cavalcante, 2008; Corrêa et al., 2016; Nelson et al., 2014; Nogueira \& Costa, 2005). Thus, the present study brings contributions to the area by exploring the profile and practices of care in the Metropolitan Region of Belém and interior of the state, revealing points of similarities and differences in the two groups.

During the collection, it was possible to experience situations of risk, these focused on the difficulty of accessing the institutions. The decentralization of services, on the one hand, is beneficial, since it shelters children from the locality, on the other; it hinders the agility of the visits, of the sectors responsible for monitoring and operation of the institutions and researchers in the area.

The results may contribute to the promotion of professional development courses aimed at the specific demands of educators, such as the training of RMB professionals to deal with issues related to children's sexuality, and in IE, to intervene in situations of physical and verbal aggression. It is also identified the possibility of appropriation of the instrument used in this study by the technical team and/or managers, so as to periodically apply it to evaluate and improve the care practices adopted in the educators' routine.

At last, the results of this study suggest investigating the influence of culture on the care practices adopted in the institutional shelter routine, taking into account the role of the male educator during early childhood at the institutions.

\section{References}

Brazil, Child and Adolescent Statute-ECA (1990). Official Diary of the Union. Law No. 
8.069, 16 July 1990. Brasília: Federal Senate. http://www.planalto.gov.br/ccivil_03/LEIS/L8069.htm

Brazil, National Council for the Rights of Children and Adolescents and the National Social Assistance Council (2009). According to the Technical Orientations for the Sheltering Services for Children and Adolescents. Brasília: Conanda.

Brazil, Presidency of the Republic, Special Secretariat for Human Rights, National Council for the Rights of Children and Adolescents (2006). National Plan for the Promotion, Protection and Defense of the Right of Children and Adolescents to Family and Community Living. Brasília: Conanda.

Bueno, R. K., Gomes, L. B., \& Crepaldi, M. A. (2015). The Importance of the Father in the Development of the Child. In E. R. Goetz, \& M. L. Vieira (Orgs.), New Father: Paths, Challenges and Possibilities (pp. 95-107). Curitiba: Juruá.

Calheiros, M. M., Garrido, M. V., Lopes, D., \& Patrício, J. N. (2015). Social Images of Residential Care: How Children, Youth and Residential Care Institutions Are Portrayed? Children and Youth Services Review, 55, 159-169.

https://doi.org/10.1016/j.childyouth.2015.06.004

Cavalcante, L. I. C. (2008). Ecology of Care: Interactions among the Child, the Environment, the Adults and the Peers in Shelter Institutions. Doctorate Thesis, Theory and Research of Behavior, Post-Graduate Program, Federal University of Pará, Belém, Brazil. http://ppgtpc.propesp.ufpa.br/ARQUIVOS/teses/Lilia Cavalcante 2008.pdf

Corrêa, L. S., \& Cavalcante, L. I. C. (2012). Profile and Trajectory of Shelter Educators Work. Cadernos de Pesquisa, 42, 494-517.

Corrêa, L. S., Cavalcante, L. I. C., Magalhães, C. M. C., \& Reis, D. C. (2016). Conceptions and Practices of Educators at Child Sheltering Institutions. Early Child Development and Care, 186, 1604-1614. https://doi.org/10.1080/03004430.2015.1117076

Coutinho, M. J., \& Sani, A. I. (2010). Shelter Home: A Solution or a Problem? Psicologia: Teoria e Pesquisa, 26, 633-641. https://doi.org/10.1590/S0102-37722010000400007

Golin, G., \& Benetti, S. P. D. C. (2013). Early Sheltering and Bonding in Institution. Psicologia: Teoria e Pesquisa, 29, 241-248.

https://doi.org/10.1590/S0102-37722013000300001

Lima, A. K., \& Lima, A. D. O. (2012). Neuropsychomotor Develompent Profile and Family Aspects of Institutionalized Children Living in Recife. Revista CES Psicología, 5, 11-25. http://www.redalyc.org/pdf/4235/423539529003.pdf

Magalhães, C. M. C., Costa, L. N., \& Cavalcante, L. I. C. (2011). The Perception of Shelter Care Educators: Their Work and the Institutionalized Child. Revista Brasileira de Crescimento e Desenvolvimento Humano, 21, 818-831.

http://pepsic.bvsalud.org/scielo.php?script=sci_arttext\&pid=S0104-1282201100030000 $8 \& \operatorname{lng}=\mathrm{pt} \& \mathrm{nrm}=\mathrm{iso} \& \mathrm{tlng}=\mathrm{pt}$

Moré, C. L. O. O., \& Sperancetta, A. (2010). Practices Developed by Social Parents in Institutions for Shelter of Children and Adolescents. Psicologia \& Sociedade, 22, 519528. https://doi.org/10.1590/S0102-71822010000300012

Müller, F. (2014). The Views of Children Living in Care Concerning Their Families of Origin. Linhas Críticas, 20, 125-145.

http://periodicos.unb.br/index.php/linhascriticas/article/view/9335/7748

Nelson, C. A., Fox, N. A., \& Zeanah, C. H. (2014). Romania's Abandoned Children: Deprivation, Brain Development, and the Struggle for Recovery. Cambridge, MA: Harvard University Press. https://doi.org/10.4159/harvard.9780674726079

Nogueira, P. C., \& Costa, L. F. (2005). Social Mother: Profession? Motherhood Role? Estilos da Clinica, 10, 162-181. 
http://pepsic.bvsalud.org/scielo.php?script=sci_arttext\&pid=S1415-7128200500020001 $0 \& \operatorname{lng}=\mathrm{pt} \& \mathrm{nrm}=\mathrm{iso} \& \operatorname{lng}=\mathrm{pt}$

Pereira, A. L., Pereira, F., \& Johnson, G. A. (2010). Daily Challenges Faced by the Workers of a Foster Care Institution for Children and Adolescents. Emancipação, 11, 189-201.

Quiroga, M. G., \& Hamilton-Giachritsis, C. (2016). Attachment Styles in Children Living in Alternative Care: A Systematic Review of the Literature. Child \& Youth Care Forum, $45,625-653$.

Rizzini, I., \& Rizzini, I. (2004). The Institutionalization of Children in Brazil: Historical Paths and Challenges of the Present. Rio de Janeiro: PUC Rio.

Tinoco, V., \& Franco, M. H. P. (2011). Coping with Bereavement in Children's Sheltering. Estudos de Psicologia (Campinas), 28, 427-434.

https://doi.org/10.1590/S0103-166X2011000400003

Submit or recommend next manuscript to SCIRP and we will provide best service for you:

Accepting pre-submission inquiries through Email, Facebook, LinkedIn, Twitter, etc. A wide selection of journals (inclusive of 9 subjects, more than 200 journals) Providing 24-hour high-quality service User-friendly online submission system Fair and swift peer-review system Efficient typesetting and proofreading procedure Display of the result of downloads and visits, as well as the number of cited articles Maximum dissemination of your research work

Submit your manuscript at: http://papersubmission.scirp.org/

Or contact psych@scirp.org 